\title{
PEMANFAATAN FLAVONOID EKSTRAK DAUN KATUK (Sauropus androgynus (L) Merr) SEBAGAI ANTIOKSIDAN PADA MINYAK KELAPA
}

\author{
Indah Cikita, Ika Herawati Hasibuan, Rosdanelli Hasibuan \\ Departemen Teknik Kimia, Fakultas Teknik, Universitas Sumatera Utara \\ Jl. Almamater Kampus USU Medan, 20155 Indonesia \\ Email: cikita_indah17@yahoo.com
}

\begin{abstract}
Abstrak
Dalam penelitian ini, daun katuk (Sauropus androgynus (L) Merr) diekstraksi untuk memperoleh flavonoid yang akan digunakan sebagai antioksidan pada minyak kelapa. Penelitian ini bertujuan untuk mengetahui pengaruh waktu ekstraksi, volume pelarut dan jenis pelarut terhadap rendemen dan kadar flavonoid total ekstrak daun katuk serta mengetahui pengaruh kadar flavonoid total dan waktu kontak flavonoid ekstrak daun katuk sebagai antioksidan pada minyak kelapa. Proses yang digunakan adalah ekstraksi daun katuk menggunakan pelarut etanol, n-heksana dan etil asetat kemudian hasil ekstrak akan dianalisa rendemen dan kadar flavonoid total. Selanjutnya ekstrak dengan kadar flavonoid total sebesar $6,668 \%, 7,748 \%$ dan $27,909 \%$ digunakan sebagai sampel dan dikontakkan pada minyak kelapa dengan waktu kontak 2, 4 dan 6 hari kemudian dilakukan analisa pada minyak kelapa yaitu bilangan asam, bilangan iod dan bilangan peroksida. Hasil penelitian yang diperoleh pada penelitian ini adalah pada waktu ekstraksi terbaik 6 jam dengan volume pelarut $1250 \mathrm{ml}$ dengan jenis pelarut terbaik etanol, diperoleh rendemen ekstrak sebesar 0,243\% dan kadar flavonoid total sebesar $27,909 \%$. Selain itu diperoleh kadar flavonoid total yang semakin meningkat menyebabkan penurunan bilangan asam, peningkatan bilangan iod dan penurunan bilangan peroksida yang membuktikan bahwa ekstrak daun katuk dapat digunakan sebagai antioksidan pada minyak kelapa dengan hasil terbaik yaitu kadar flavonoid sebesar 27,909\% dimana bilangan asam 0,962 mg KOH/g, bilangan iod 38,705 $\mathrm{g} \mathrm{I}_{2} / 100 \mathrm{~g}$ dan bilangan peroksida 13,333 Meq/kg. Waktu kontak flavonoid pada minyak kelapa yang semakin meningkat menyebabkan sifat minyak semakin buruk tetapi hasilnya lebih baik dibandingkan minyak tanpa penambahan ekstrak.
\end{abstract}

Kata kunci : ekstraksi, flavonoid, minyak kelapa, antioksidan, ekstrak daun katuk

\begin{abstract}
In this research, the katuk leaves (Sauropus androgynus (L) Merr) extracted for get flavonoid which used as antioxidant for the coconut oil. This research aims to determine the effect of the extraction time, the volume of the solvent, and the type of solvent for the yield and total flavonoid concentration of the katuk leaves extract and then to determine the effect of total flavonoid concentration and contact time the flavonoid of katuk leaves extract as antioxidants in coconut oil. The process used is extraction of katuk leaves used the solvent such as ethanol, $n$-heksana and etil asetat then extract will be analysed the yield and total flavonoid concentration of the katuk leaves extract. Then extract with the total flavonoid concentration 6,668\%, 7,748\% and 27,909\% was used as a sample and contacted in the coconut oil with the contact time of 2, 4 and 6 days. Then, analysis is done of the coconut oil is the acid number, the iodine number and the peroxide number. The result obtained in this research is the best extraction time of 6 hours with solvent volume of $1250 \mathrm{ml}$ with the best type of solvent is ethanol, the yield of extract is 0,243\% and total flavonoid concentration is 27,909\%. The total flavonoid concentration increasing cause a decrease the acid number, the iodine number increase and decrease the peroxide number which proved that katuk leaves extract can be used as antioxidants in the coconut oil with the best result is the total flavonoid concentration in 27,909\% where the acid number is $0,962 \mathrm{mg} \mathrm{KOH} / \mathrm{g}$, the iodine number is $38,705 \mathrm{~g} \mathrm{I}_{2} / 100 \mathrm{~g}$ and the peroxide number is $13,333 \mathrm{Meq} / \mathrm{kg}$. The contact time of flavonoid in the coconut oil which increasing cause oil properties is getting worse but the results are better than the oil without the addition of extract.
\end{abstract}

Keywords : extraction, flavonoid, coconut oil, antioxidant, katuk leaves extract

\section{Pendahuluan}

Pengembangan produk minyak kelapa untuk memenuhi kebutuhan pangan di Indonesia memiliki prospek yang baik untuk jangka panjang. Hal tersebut karena Indonesia memiliki potensi area perkebunan kelapa yang luas bila dibandingkan dengan negara-negara penghasil kelapa yang lainnya. Menurut data Coconut Statistical Yearbook pada tahun 2006, luas area perkebunan kelapa di Indonesia yaitu 3.701 Ha. Minyak kelapa mudah mengalami proses oksidasi sehingga menghasilkan senyawa yang menyebabkan terjadinya off flavour 
yang biasa disebut tengik (rancid). Hal ini menyebabkan produk olahan pangan akan menurun menurun mutunya dan membahayakan manusia. Salah satu cara mengatasinya adalah menambahkan antioksidan [17].

Penggunaan antioksidan sintetik seperti BHA (Butilated Hidroxy Anisol) dan BHT ( Butilated Hidroxy Toluena) sangat efektif untuk menghambat minyak atau lemak agar tidak terjadi oksidasi, namun penggunaan BHA dan BHT banyak menimbulkan kekhawatiran akan efek sampingnya. Untuk menghindari efek antioksidan yang berbahaya maka cara yang paling aman adalah penggunaan antioksidan alami [3].

Salah satu bahan alami yang dapat digunakan sebagai antioksidan adalah daun katuk. Katuk merupakan jenis tanaman tahunan yang setiap saat dapat dipetik dan tidak tergantung pada musim [13]. Daun katuk dapat bekerja sebagai antioksidan yang ditunjukkan oleh adanya senyawa golongan fenol yaitu flavonoid. Tulisan ini memaparkan hasil keefektifan flavonoid yang berasal dari ekstrak daun katuk sebagai antioksidan pada minyak kelapa.

\section{Teori}

Sauropus androgynus (L) Merr yang disebut juga daun manis atau katuk adalah jenis semak yang termasuk ke dalam famili Euphorbiaceae, yang tumbuh di daerah tropis yang hangat dan lembab dan biasa digunakan sebagai sayuran [16].

Antioksidan adalah senyawa kimia yang dapat menunda awal atau memperlambat laju reaksi oksidasi lemak dalam sistem pangan atau membantu menetralisir radikal bebas [18]. Daun katuk dapat bekerja sebagai antioksidan yang ditunjukkan oleh adanya senyawa golongan fenol yaitu flavonoid [2]. Flavonoid merupakan kelompok besar fitokimia yang bersifat melindungi dan banyak terdapat pada buah dan sayuran. Flavonoid sering dikenal sebagai bioflavonoid yang berperan sebagai antioksidan. Flavonoid adalah bagian dari senyawa fenolik yang terdapat pada pigmen tumbuh-tumbuhan. Kesehatan manusia sangat tergantung pada flavonoid sebagai antioksidan untuk mencegah kanker [22].

Ekstraksi adalah suatu cara untuk memisahkan campuran beberapa zat menjadi komponenkomponen yang terpisah. Ekstraksi juga dapat diartikan sebagai proses penarikan komponen atau zat aktif menggunakan pelarut tertentu [9].

Minyak kelapa merupakan bagian yang paling berharga dari buah kelapa dan banyak digunakan sebagai bahan baku industri atau sebagai minyak goreng. Minyak kelapa dihasilkan dari daging buah kelapa atau daging buah kelapa yang dikeringkan (kopra) [10]. Minyak kelapa digunakan sebagai minyak goreng, bahan margarin dan mentega putih, komponen dalam pembuatan sabun, formulasi kosmetika dan bahan farmasi [23].

\section{Metodologi Penelitian \\ Prosedur dan Analisis}

Tahapan-tahapan penelitian yang dilakukan yaitu pembuatan serbuk daun katuk, ekstraksi flavonoid daun katuk, penentuan rendemen, penentuan kadar flavonoid total dan penentuan keefektifan flavonoid sebagai antioksidan pada minyak kelapa.

Serbuk daun katuk ditimbang sebanyak 50 gr lalu ditambahkan pelarut dengan variasi jenis pelarut etanol, n-heksana dan etil asetat dan variasi volume 750, 1000 dan $1250 \mathrm{ml}$ serta variasi waktu ekstraksi yaitu 2, 4, 6 jam. Selanjutnya dimasukkan kedalam labu leher tiga dan dipanaskan dengan hote plate pada suhu $60{ }^{\circ} \mathrm{C}$ dengan kecepatan $7 \mathrm{rpm}$. Kemudian ekstrak disaring dan hasil filtrasi dipekatkan menggunakan rotary evaporator pada suhu $70{ }^{\circ} \mathrm{C}$. Setelah itu dilakukan analisa penentuan rendemen dan kadar flavonoid total ekstrak daun katuk.

Ekstrak yang memiliki kadar flavonoid total $6,668 \%, 7,748 \%$ dan 27,909\% kemudian akan digunakan untuk antioksidan pada minyak kelapa. Minyak kelapa ditimbang sebanyak 5 gram. Ekstrak diambil sebanyak 5\% dari jumlah minyak kelapa yaitu 0,25 gram dan dicampurkan dengan minyak ke dalam botol hitam. Campuran tersebut disimpan/dikontakkan sesuai variasi waktu yaitu 2, 4 dan 6 hari. Setelah itu dilakukan analisa pada minyak kelapa.

Analisa yang dilakukan adalah analisa bilangan asam, bilangan iod dan bilangan peroksida. Perubahan yang terjadi dari setiap hasil analisa akan menunjukkan keefektifan flavonoid ekstrak daun katuk sebagai antioksidan pada minyak kelapa.

\section{Hasil dan Pembahasan \\ Pengaruh Waktu Reaksi, Volume Pelarut, Dan Jenis Pelarut terhadap Rendemen Ekstrak Daun Katuk}

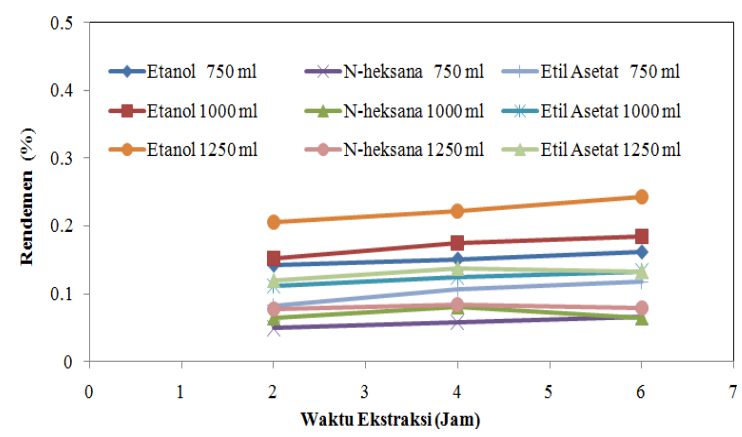

Gambar 1. Pengaruh Waktu Ekstraksi dan Volume Pelarut terhadap Rendemen dengan Jenis Pelarut Etanol, N-heksana dan Etil Asetat 
Gambar 1 menunjukkan grafik hubungan waktu ekstraksi terhadap rendemen pada jenis pelarut etanol, n-heksana dan etil asetat dengan waktu ekstraksi 2, 4, dan 6 jam dengan variasi volume pelarut 750, 1000, dan $1250 \mathrm{ml}$. Dari grafik tersebut dapat dilihat bahwa semakin lama waktu ekstraksi dan semakin banyak volume pelarut maka rendemen yang diperoleh semkain meningkat pada masing-masing jenis pelarut yang digunakan.

Dari grafik dapat dilihat bahwa semakin lama waktu ekstraksi maka rendemen yang diperoleh semakin besar, hal ini disebabkan karena lamanya waktu operasi pada proses ekstraksi yang membuat kontak antara solven dengan bahan baku (daun katuk) semakin lama sehingga proses pelarutan dari rendemen oleh daun katuk terjadi terus menerus sampai pelarut jenuh terhadap bahan baku. Namun jika waktu reaksi terlalu lama maka peruses ekstraksi akan mengalami kerusakan dan mengurangi hasil rendemen yang diperoleh [7]. Begitu juga halnya dengan volume pelarut, semakin banyak volume pelarut maka rendemen akan semakin besar sehingga dapat menentukan nilai rendemen yang tinggi. Akan tetapi jika volume pelarut terlalu banyak maka rendemen yang diperoleh akan mengalami penurunan. Karena semakin banyak pelarut yang digunakan akan menyebabkan perubahan sifat dan komposisi dari ekstrak daun katuk sehingga mudah menguap dan akhirnya terkondensasi. Untuk jenis pelarut yang digunakan bahwa hasil dari rendemen yang diperoleh berbeda-beda dari masing-masing pelarut disebabkan karena sifat polar dan tidaknya pelarut yang dipakai. Semakin polar pelarut yang digunakan maka daya ekstraksi akan semakin bagus [20].

Semakin tinggi tingkat kepolaran dari pelarut maka rendemen yang diperoleh semakin meningkat, semakin polar pelarut maka daya ekstraksi akan semakin bagus [5]. Dari ketiga jenis pelarut diperoleh bahwa jenis pelarut etanol yang menunjukkan hasil terbaik dimana memberikan rendemen yang paling besar dibandingkan jenis pelarut $n$-heksana dan etil asetat. Semakin tinggi tingkat kepolaran dari pelarut maka rendemen yang diperoleh semakin meningkat proses penarikan bahan (ekstraksi) terjadi dengan mengalirnya pelarut ke dalam sel bahan yang menyebabkan protoplasma membengkak, dan kandungan sel dalam bahan akan terlarut sesuai dengan kelarutannya. Daya melarutkan yang tinggi berhubungan dengan kepolaran pelarut dan kepolaran bahan yang diekstraksi.

Dari hasil penelitian diperoleh bahwa waktu ekstraksi adalah 2 jam pada volume pelarut 1250 $\mathrm{ml}$ dengan jenis pelarut etanol.

\section{Pengaruh Waktu Reaksi, Volume Pelarut, Dan Jenis Pelarut terhadap Kadar Flavonoid Total Ekstrak Daun Katuk}

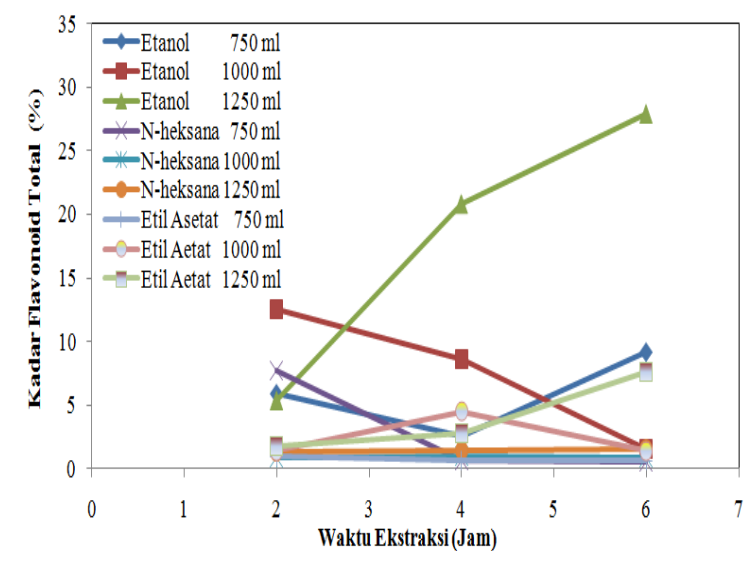

Gambar 2. Pengaruh Waktu Ekstraksi dan Volume Pelarut terhadap Kadar Flavonoid Total dengan Jenis Pelarut Etanol, N-heksana dan Etil Asetat

Gambar 2 menunjukkan grafik hubungan waktu reaksi terhadap kadar flavonoid pada jenis pelarut etanol, n-heksana dan etil asetat dengan waktu ekstraksi 2, 4, dan 6 jam dengan variasi volume pelarut 750, 1000, dan $1250 \mathrm{ml}$. Dari grafik dapat dilihat bahwa semakin lama waktu ekstraksi dan semakin banyak volume pelarut yang digunakan maka kadar flavonoid total yang diperoleh terjadi fluktuatif (kenaikan/penurunan). Pada grafik tersebut juga menunjukkan hubungan jenis pelarut terhadap kadar flavonoid total. Dari grafik dapat dilihat bahwa ketiga jenis pelarut tersebut yaitu etanol, n-heksana dan etil asetat memberikan hasil yang masih fluktuatif tetapi pada pelarut etanol diperoleh kadar flavonoid yang lebih besar dibandingkan jenis pelarut yang lain.

Menurut penelitian sebelumnya, seiring dengan meningkatnya waktu ekstraksi dan dengan waktu yang berkelanjutan maka akan berpotensi meningkatkan proses hilangnya pelarut dengan penguapan [15]. Dengan demikian penggunaan kadar flavonoid digunakan untuk menentukan efesiensi ekstrak pelarut. Akan tetapi suatu pelarut memiliki kemampuan terbatas dan suhu optimum untuk mencapaiproses menghilangnya pelarut (proses penguapan), sehingga dioeroleh pelarut terbaik yang menghasilkan kadar flavonoid terbanyak dari bahan ekstrak, sehingga ekstraksi dilakukan dengan variasi pelarut lainnya.

Apabila telah diperoleh kadar flavonoid total dari bahan yang diekstrak dan mempunyai titik maksimum pada waktu reaksi tertentu, sehingga ekstraksi dilakukan dengan menggunakan waktu ekstraksi dan jenis pelarut lainnya sehinga 
diperoleh kadar total flavonoid dari masing-masing variabel. Setelah senyawa polifenol pada ekstrak diperoleh, maka polifenol (flavonoid) yang dihasilkan dapat digunakan sebagai antioksidan yang digunakan untuk menetralisir radikal bebas pada antioksidan dan kemudian akan menghasilkan nilai bilangan peroksida. Menurut penelitian sebelumnya yang dilakukan oleh Mandana Bimark,"semakin banyak volume pelarut, maka semakin besar rendemen hasil dari ekstrak". Dengan demikian maka volume pelarut digunakan untuk menentukan nilai rendemen tertinggi untuk senyawa flavonoid [14].

Untuk menunjukkan bahwa flavonoid ekstrak daun katuk memberikan hasil dapat digunakan sebagai antioksidan pada minyak kelapa maka terlebih dahulu dilakukan pengujian terhadap minyak kelapa tanpa penambahan ekstrak daun katuk. Hasil yang diperoleh seperti pada tabel 1 berikut.

Tabel 1. Hasil Pengujian Minyak Kelapa tanpa Penambahan Ekstrak Daun Katuk

\begin{tabular}{|c|c|c|c|c|}
\hline $\begin{array}{c}\text { Kadar Flavonoid } \\
\text { Total } \\
(\%)\end{array}$ & $\begin{array}{l}\text { Waktu } \\
\text { Kontak } \\
\text { (Hari') }\end{array}$ & $\begin{array}{c}\text { Bilangan } \\
\text { Asam } \\
(\mathrm{mg} \mathrm{KOH} / \mathrm{g})\end{array}$ & $\begin{array}{l}\text { Bilangan } \\
\text { Iod } \\
(\mathrm{g} I / 2 / 100 \mathrm{~g})\end{array}$ & $\begin{array}{l}\text { Bilangan } \\
\text { Peroksida } \\
\text { (Meglkg) }\end{array}$ \\
\hline \multirow{3}{*}{0} & 2 & 2,030 & 24,190 & 24,762 \\
\hline & 4 & 2,351 & 14,514 & 32,381 \\
\hline & 6 & 2,885 & 4,838 & 42,857 \\
\hline
\end{tabular}

Pengaruh Waktu Kontak dan Kadar Flavonoid Total Terhadap Bilangan Asam Pada Minyak Kelapa

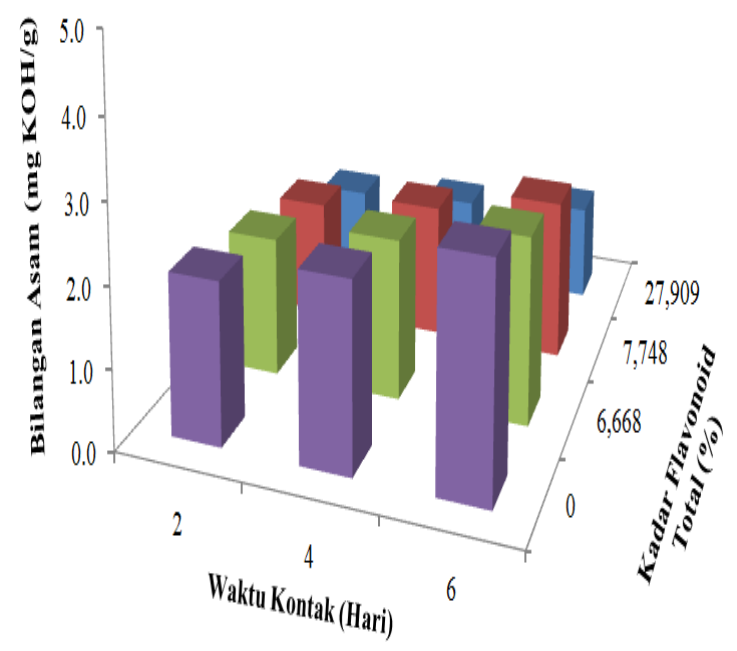

Gambar 3. Pengaruh Waktu Kontak dan Kadar Flavonoid Total Terhadap Bilangan Asam Pada Minyak Kelapa
Gambar 3 menunjukkan grafik pengaruh waktu kontak dan kadar flavonoid total terhadap bilangan asam pada minyak kelapa. Dari grafik dapat dilihat bahwa semakin lama waktu kontak maka bilangan asam minyak kelapa semakin meningkat dan semakin besar kadar flavonoid total maka bilangan asam minyak kelapa semakin menurun.

Pada periode oksidasi yang semakin lama maka bilangan asam minyak juga semakin tinggi. Selama periode oksidasi, minyak mengalami degradasi yang menyebabkan terbentuknya asam lemak rantai pendek hasil penguraian senyawa peroksida dan asam lemak bebas [12]. Penambahan antioksidan dikatakan efektif jika mampu menahan oksidasi yang ditunjukkan dengan kenaikan bilangan asam yang tidak terlalu tinggi dibandingkan jika tanpa penambahan antioksidan [24].

Penambahan antioksidan dapat menurunkan kadar asam lemak bebas secara signifikan [21]. Pengaruh penambahan antioksidan dalam menghambat kenaikan bilangan asam berawal dari penghambatan pembentukan peroksida melalui donor atom $\mathrm{H}$ sehingga radikal lipid yang terbentuk menjadi lebih stabil. Kadar atau konsentrasi antioksidan yang ditambahkan memiliki pengaruh terhadap kenaikan bilangan asam. Semakin tinggi kadar atau konsentrasi yang ditambahkan maka bilangan asam yang dihasilkan akan semakin menurun [4].

\section{Pengaruh Waktu Kontak dan Kadar Flavonoid Total Terhadap Bilangan Iod Pada Minyak Kelapa}

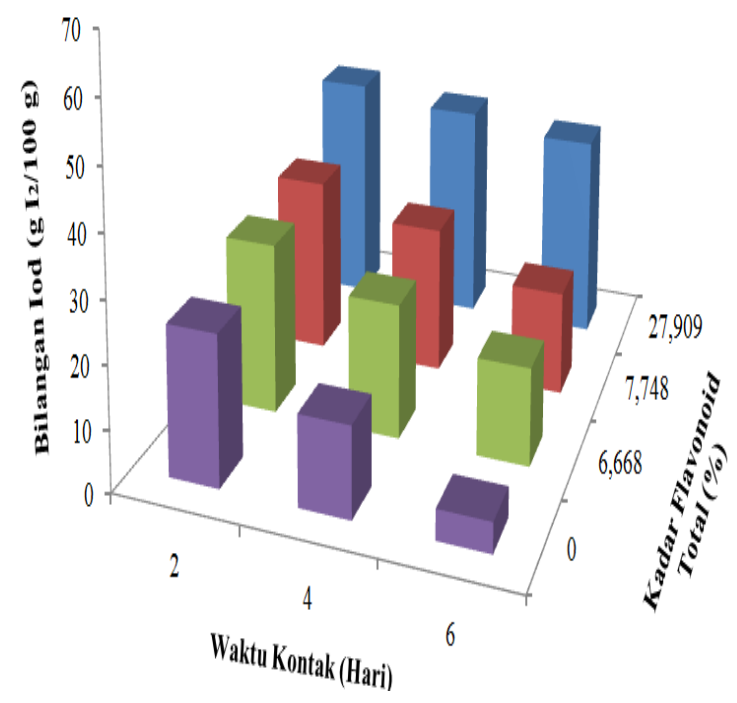

Gambar 4. Pengaruh Waktu Kontak dan Kadar Flavonoid Total Terhadap Bilangan Iod Pada Minyak Kelapa 
Gambar 4 menunjukkan grafik pengaruh waktu kontak dan kadar flavonoid total terhadap bilangan iod pada minyak kelapa. Dari grafik dapat dilihat bahwa semakin lama waktu kontak maka bilangan iod minyak kelapa semakin menurun dan semakin besar kadar flavonoid total yaitu maka bilangan iod minyak kelapa semakin meningkat.

Periode oksidasi yang semakin lama menyebabkan penurunan bilangan iod. Penurunan bilangan iod berhubungan dengan terbentuknya senyawa peroksida akibat oksidasi dan polimerisasi oksidasi yang terjadi. Semakin banyak senyawa peroksida yang terbentuk selama periode oksidasi, maka bilangan iod semakin menurun. Dengan adanya antioksidan, proses oksidasi dapat dihambat sehingga degradasi minyak dapat diperlambat. Minyak tanpa penambahan antioksidan mengalami penurunan bilangan iod yang lebih besar, hal ini menunjukkan bahwa reaksi oksidasi dan polimerisasi yang menyebabkan terputusnya ikatan rangkap berlangsung dengan cepat [24].

Banyaknya iod yang diikat menunjukkan banyaknya ikatan rangkap yang terdapat pada minyak. Hal ini menunjukkan bahwa semakin tinggi bilangan iod maka semakin baik kualitas minyak atau lemak [1]. Penambahan antioksidan dapat menghalangi oksigen berikatan dengan ikatan rangkap asam lemak. Banyaknya antioksidan yang diberikan menyebabkan proses oksidasi berjalan lambat karena oksigen yang berikatan dengan ikatan rangkap semakin sedikit sehingga bilangan iodin semakin tinggi. Semakin tinggi bilangan iodin, maka kualitas minyak semakin baik [8].

\section{Pengaruh Waktu Kontak dan Kadar Flavonoid Total Terhadap Bilangan Peroksida Pada Minyak Kelapa}

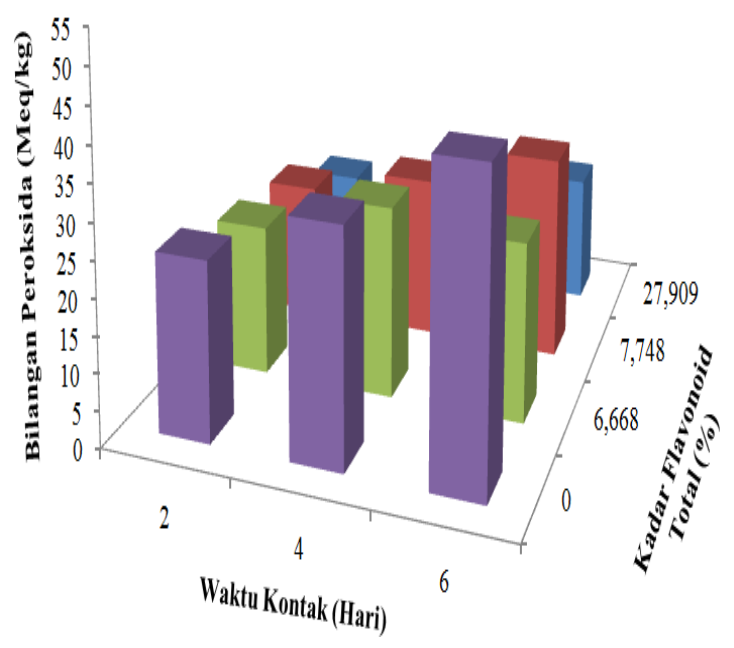

Gambar 5. Pengaruh Waktu Kontak dan Kadar Flavonoid Total Terhadap Bilangan Peroksida Pada Minyak Kelapa
Gambar 5 menunjukkan grafik pengaruh waktu kontak dan kadar flavonoid total terhadap bilangan peroksida pada minyak kelapa. Pada grafik dapat dilihat bahwa semakin lama waktu kontak maka bilangan peroksida minyak kelapa semakin meningkat. Akan tetapi grafik pada kadar $6,668 \%$ terjadi penyimpangan yaitu pada waktu kontak 6 hari, bilangan peroksida mengalami penurunan tetapi penurunan yang terjadi tidak begitu besar. Selain itu, semakin besar kadar flavonoid total maka bilangan peroksida minyak kelapa semakin menurun. Tetapi grafik pada waktu kontak 6 hari terjadi penyimpangan dimana pada kadar flavonoid total $7,748 \%$, bilangan peroksida mengalami kenaikan kemudian mengalami penurunan kembali pada kadar flavonoid total $27,909 \%$. Adanya penyimpangan ini kemungkinan disebabkan kadar flavonoid total $7,748 \%$ tidak terlalu jauh perbedaannya dari kadar flavonoid total sebelumnya yaitu $6,668 \%$ sehingga tidak mampu menghambat reaksi oksidasi yang terjadi.

Bilangan peroksida dapat meningkat dengan bertambahnya waktu penyimpanan (waktu kontak), suhu dan udara [19]. Pada periode oksidasi yang semakin lama, bilangan peroksida minyak semakin bertambah. Kecenderungan peningkatan bilangan peroksida ini menunjukkan bahwa minyak mengalami kerusakan selama periode oksidasi akibat terbentuknya senyawa peroksida dalam minyak [24]. Dapat dikatakan bahwa penggunaan antioksidan menghambat proses oksidasi, sehingga walaupun tetap terjadi oksidasi dengan meningkatnya waktu penyimpanan tetapi banyaknya peroksida yang terbentuk lebih sedikit dibandingkan minyak tanpa penggunaan antioksidan [11].

Peroksida terbentuk pada tahap inisiasi oksidasi, pada tahap ini hidrogen akan menghasilkan radikal bebas. Radikal bebas yang terbentuk bereaksi dengan oksigen membentuk radikal peroksi, selanjutnya atom hidrogen dari molekul tak jenuh lain menghasilkan peroksida dan radikal bebas yang baru [6]. Penambahan antioksidan mampu menekan peningkatan bilangan peroksida. Antioksidan yang paling efektif merupakan antioksidan yang mampu menahan oksidasi yang ditunjukkan dengan kenaikan bilangan peroksida yang kecil. Semakin tinggi konsentrasi atau kadar antioksidan yang diberikan maka nilai bilangan peroksidanya semakin rendah. Konsentrasi atau kadar antioksidan yang kurang maksimal maka mengakibatkan kemampuan menghambat reaksi oksidasi juga semakin kecil [4].

\section{Kesimpulan}

Kesimpulan yang dapat diambil dari penelitian yang telah dilakukan adalah : 
1. Semakin lama waktu ekstraksi maka rendemen ekstrak daun katuk semakin meningkat dan kadar flavonoid total terjadi fluktuatif.

2. Semakin besar volume pelarut maka rendemen ekstrak daun katuk semakin meningkat dan kadar flavonoid total terjadi fluktuatif.

3. Jenis pelarut mempengaruhi rendemen dan kadar flavonoid total ekstrak daun katuk. Jenis pelarut yang memberikan hasil terbaik yaitu etanol.

4. Ekstrak daun katuk yang memiliki kadar flavonoid total sebesar $6,668 \%, 7,748 \%$ dan $27,909 \%$ dimana semakin besar kadarnya dapat menghasilkan penurunan bilangan asam, peningkatan bilangan iod dan penurunan bilangan peroksida pada minyak kelapa. Hal ini membuktikan bahwa flavonoid ekstrak daun katuk dapat digunakan sebagai antioksidan pada minyak kelapa.

5. Peningkatan waktu kontak flavonoid membuat kualitas antioksidan semakin buruk. Waktu kontak flavonoid yang semakin meningkat yaitu selang waktu 2, 4 dan 6 hari akan meningkatkan bilangan asam, menurunkan bilangan iod dan meningkatkan bilangan peroksida pada minyak kelapa.

6. Ekstrak daun katuk dengan kadar flavonoid total tertinggi yaitu $27,909 \%$ memberikan hasil terbaik sebagai antioksidan pada minyak kelapa yaitu dengan hasil bilangan asam terkecil sebesar 0,962 $\mathrm{mg} \mathrm{KOH} / \mathrm{g}$, bilangan iod terbesar sebesar $38,705 \quad \mathrm{~g} \quad \mathrm{I}_{2} / 100 \mathrm{~g}$ dan bilangan peroksida terkecil sebesar 13,333 Meq/kg.

\section{Daftar Pustaka}

[1] Agus Triyanto, Peningkatan Kualitas Minyak Goreng Bekas Menggunakan Arang Ampas Tebu Teraktivasi dan Penetralan denga NaHSO3, Skripsi, Jurusan Kimia FMIPA Universitas Negeri Semarang, Semarang, 2013.

[2] Ajit B. Patil, Asha S. Jadhav, Flavonoid an Antioxidant : A Review, International Journal of Pharmaceutical and Biological Sciences Research and Devlopment, IJPBSRD 1 (2), Oktober 2013 : hal. $07-20$.

[3] Ana Andari, Uji Aktivitas Ekstrak Daun Katuk (Saoropus androgynus L.Merr) sebagai Antioksidan Pada Miyak Kelapa, Skripsi, Program Studi Kimia Fakultas Sains dan Teknologi UIN Sunan Kalijaga, Yogyakarta, 2010.

[4] Arum Anggraini, Pengaruh Jenis dan Konsentrasi Antioksidan terhadap Ketahanan Oksidasi Biodiesel dari Jarak Pagar (Jatropha Curcas, L), Skripsi, Fakultas Teknologi Pertanian IPB, Bogor, 2007.
[5] Budi Nugroho, Pengaruh Suhu Ekstraksi Terhadap Kandungan Kurkuminoid Dan Air Serbuk Temulawak (Curcuma Xanthorrhiza), Metode Penelitian Percobaan, Diklat Metode Penelitian Dan Pengolahan Data Lembaga Ilmu Pengetahuan Indonesia 2008.

[6] Chairunisa, Uji Kualitas Minyak Goreng Pada Pedagang Gorengan di Sekitar Kampus UIN Syarif Hidayatullah Jakarta, Skripsi, Fakultas Kedokteran dan Ilmu Kesehatan Program Studi Farmasi, Jakarta, 2013.

[7] Dewi Maulida, Naufal Zulkarnaen, Proses Antioksidan Likopen dari Buah Tomat dengan Menggunakan Solven Campuran N-heksana, Aseton dan Etanol, Tugas Akhir Program Sarjana, Jurusan Teknik Kimia, Fakultas Teknik, Universitas Semarang, 2010.

[8] Fahrurizal Laitupa, Hism Susane, Pemanfaatan Eugenol dari Minyak Cengkeh untuk Mengatasi Ranciditas Pada Minyak Kelapa, Jurusan Teknik Kimia Fakultas Teknik Universitas Diponegoro, Semarang, 2010.

[9] Farah Umar, Optimisasi Ekstraksi Flavonoid Total Daun Jati Belanda, Skripsi, Departemen Kimia FMIPA IPB, Bogor, 2008.

[10] Gopala Krishna A. G, Gaurav Raj, Ajit Singh Bhatnagar, Prasanth kumar P. K, Preeti Chandrashekar, Coconut Oil : Chemistry, Production and Its Applications - A Review, Indian Coconut Journal, Department of Lipid Science and Traditional Foods, Central Food Technological Research Institute (CSIR), Mysore, 2010.

[11] Han Roliadi, R. Sudrajat, Arum Anggraini, Kemungkinan Penggunaan Antioksidan Guna Mempertinggi Ketahanan Oksidasi Biodiesel dari Minyak Biji Tanaman Jarak Pagar (Jatropha curcas L.), Jurnal Penelitian hasil Hutan, Vol. 30, No. 1, Maret 2012 : hal. $69-86$.

[12] I. Sani, C. Owoade, A. Abdulhamid, Isah M. Fakai, F. Bello, Evaluation of Physicochemical Properties, Phytochemicals and Mineral Composition of Cocosnuciferal. (Coconut) Kernel Oil, International Journal of Advanced Research in Chemical Science, Volume 1, Issue 8, Oktober 2014 : hal. 22 30.

[13] Mahareni Septyana, Performa Itik Petelur Lokal dengan Pemberian Tepung Daun Katuk (Saoropus androgynus L.Merr) dalam Ransumnya, Skripsi, Program Studi Ilmu Nutrisi dan Makanan Ternak Fakultas Peternakan IPB, Bogor, 2008.

[14] Mandana Bimakr, dkk, Comparison of Different Extraction Methods for The Extraction of Major Bioactive Flavonoid 
Compounds from Spearmint (Mentha spicata L.) Leaves, Journal of Food and Bioproducts Processing, Faculty of Engineering, University Putra Malaysia, Selangor, Malaysia : hal. $67-72$.

[15] Mohamed Ali ar-Farsi and Chang Yong Lee, Optimization of Phenolics and Dietary Fibre Extraction from Date Seeds, Journal of Food Science and Technology, Cornell University, Geneva, New York, USA, 2008 : hal. 977 985.

[16] Muhammad Haris, Penentuan Kadar Flavonoid Total dan Aktifitas Antioksidan dari Daun Dewa (Gynura pseudochina [Lour] DC) dengan Spektrofotometer UV-Visibel,. Skripsi, Fakultas Farmasi Universitas Andalas, Padang, 2011.

[17] Osy Yostia Utami, Komponen Minyak Atsiri Daun Sirih (Piper betle L.) dan Potensinya dalam Mencegah Ketengikan Minyak Kelapa,

Skripsi, Departemen Biokimia Fakultas MIPA IPB, Bogor, 2011.

[18] Pandurangan R.K, Murugesan S, Gajivaradhan P, Physico Chemical Properties of Groundnut Oil and Their Blends with Other Vegetables Oil, Journal of Chemical and Pharmaceutical Research, 6 (8), 2014 : hal. 60 $-66$.

[19] P Eganathan, Ajay Parida, Micropropagation of Sauropus androgynus (L.) Merr An Important Green Leafy Vegetable, Indian Journal of Biotechnology, Vol 11 (April), 2013 : hal. $235-237$.

[20] Petrus Darmawan, Pengaruh Jenis Pelarut terhadap Rendemen Terhadap Minyak Bunga Cengkeh Mengggunakan Metode Ekstraksi Soxhletasi, Jurnal Teknik Kimia Universitas Setia Budi, Surakarta, 2009.

[21] Ratna Dewi Mayasari Yudhaningtyas, Pengaruh Level Pemberian BHT (Butylated Hidroxy Toluene) dan Lama Penyimpanan terhadap Kadar Air, Kadar Asam Lemak Bebas, dan Angka Peroksida Bungkil Kelapa, Skripsi, Jurusan Nutrisi Makanan Ternak Fakultas Peternakan Universitas Brawijaya, Malang, 2008.

[22] Sabri Sudirman, Aktivitas Antioksidan dan Komponen Bioaktif Kangkung Air, Skripsi, Departemen Teknologi Hasil Perairan fakultas Perikanan dan Ilmu Kelautan IPB, Bogor, 2011.

[23] Tri Widiandani, Purwanto, Suko Hardjono, Bambang Tri P, Rully Susilowati, Nuzul W. Diyah, Upaya Peningkatan Kualitas Minyak Kelapa yang Dibuat dari Cocos nucifera L dengan Berbagai Metode Kimiai dan Fisik, Departemen Kimia Farmasi Fakultas Farmasi Universitas Airlangga, Surabaya, 2008.
[24] Tri Yuni Hendrawati, Studi Pengaruh Penggunaan Antioksidan Golongan Phenolik dan Aminik terhadap Ketahanan Oksidasi Minyak Sawit Pada Berbagai Tingkat Kemurnian, Tesis, Program Pascasarjana IPB, 2001. 